\title{
Monitoring the impact of coastal erosion on archaeological sites: the Cyprus Ancient Shoreline Project
}

Georgia Marina Andreou*

Coastal erosion of archaeological sites has long been a problem for archaeologists seeking to understand maritime interactions in the past. A new model, using ArcGIS to collate various sources of data relating to processes of erosion over time along the south coast of Cyprus, is showcased here, with the hope that it can be expanded and adapted for use elsewhere in prioritising sites according to rates of destruction.

\section{Introduction}

Coastal sites have long been a significant focus of archaeological research, particularly in the Mediterranean, a region that is well suited to the study of maritime connectivity, trade and interaction (Knapp \& Demesticha 2017). The generally benign Mediterranean Sea regime (modest tides and wave action) has facilitated the establishment and endurance of many coastal sites throughout history, but has also contributed to their incremental exposure and erosion. Despite recent theoretical and methodological advances in coastal archaeology, ongoing erosion remains a serious predicament for both the preservation and interpretation of coastal sites. Coastal erosion often leads to an irreparable loss of information used in the identification of maritime structures and activities. The Mediterranean, then, is a hotspot of both opportunity and concern.

In light of the time and financial constraints of a large-scale systematic recording of the coastline (Agapiou et al. 2017), the Cyprus Ancient Shoreline Project (CASP) developed a classification scheme that will augment strategic planning for sustainable monitoring of continuously exposed archaeological features (Figure 1). The project focuses on the island of Cyprus and its role in the international trade networks of the Eastern Mediterranean since the second millennium BC, a subject that has received considerable attention. This preliminary analysis examines a $20 \mathrm{~km}$-long stretch of the south-central coast of Cyprus, extending from Cape Dolos to Cape Kiti (Figure 2).

\section{Coastal erosion and cultural heritage in south-central Cyprus}

South-central Cyprus is experiencing the highest rates of coastal erosion on the island. Although archaeological sites in this region have received increased attention thanks to systematic surveys (Manning et al. 1994; Manning et al. 2000; Georgiou 2013; Andreou

* Department of Classics, Cornell University, 120 Goldwin Smith Hall, 232 East Avenue, Ithaca, NY 148533201,USA (Email: gma58@cornell.edu) 


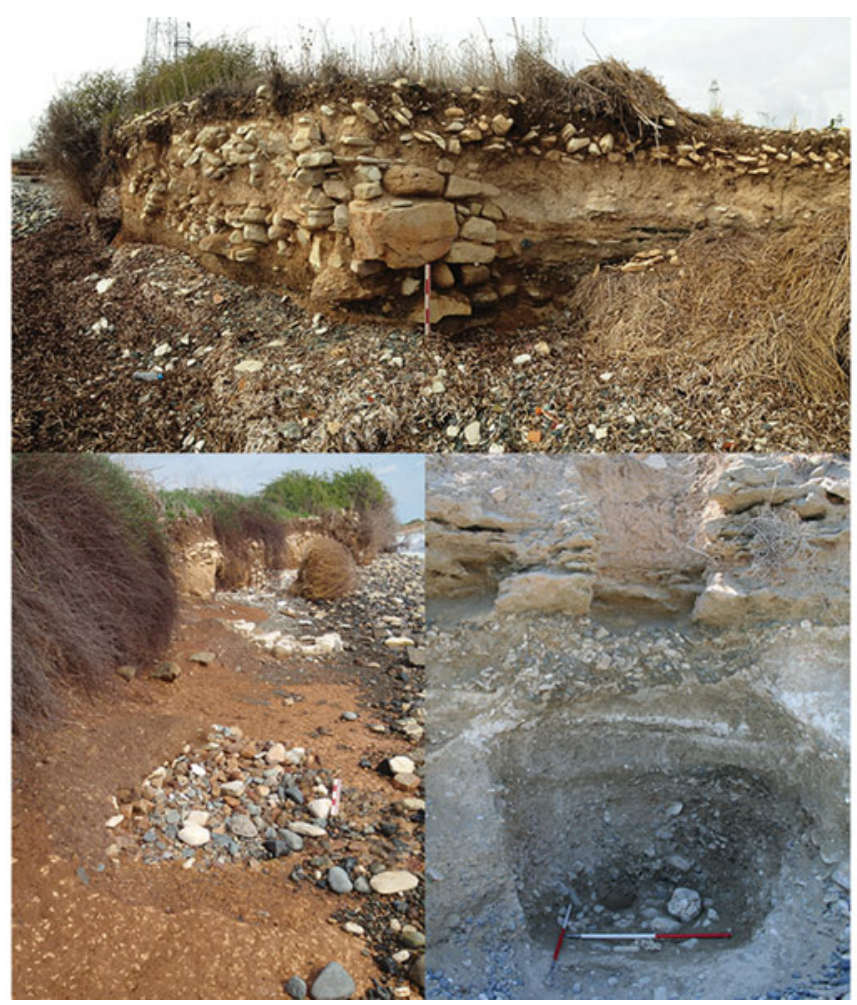

Figure 1. Examples of eroding archaeological features from Cyprus recorded by the Cyprus Ancient Shoreline Project. Top: wall (1m preserved height, $1.2 \mathrm{~m}$ width, $5.5 \mathrm{~m}$ of maximum exposed length), containing stratified Late Bronze and Early Iron Age pottery found at Tochni-Lakkia, a site with evidence for large-scale storage and possibly also pottery production; bottom left: the remains (base) of a stone-filled pit found at Tochni-Lakkia; bottom right: rescue-excavated tomb exposed at Maroni-Tsaroukkas, a Late Bronze Age site with significant evidence for international interaction (imported artefacts, anchors, boat models), as well as monumental architecture (photographs by the author and Sturt Manning).

\& Sewell 2015; Demesticha 2015), the impact of coastal erosion has only recently been investigated from a cultural heritage perspective (Agapiou et al. 2017; Andreou et al. 2017). Since 2014, the CASP has compiled historical (medieval maps), archaeological (terrestrial and underwater survey) and geographical (aerial photographs) information to reconstruct historical coastlines in this region digitally, and to map sites that are under threat. More recently, this dataset was examined to classify the severity of coastal erosion, and to highlight the areas that require more frequent recording.

\section{Erosion classification and archaeological risk assessment}

To classify the severity of coastal erosion in segments of 20m, CASP used the Digital Shoreline Analysis System (DSAS), a toolbar for ArcGIS that allows a detailed analysis of diachronic changes in the coastline (Thieler et al. 2009; Radosavljevic et al. 2016; O'Rourke 2017). The classification process compares the location of digitised historical shorelines (Andreou et al. 2017) through the generation of perpendicular transects with customisable lengths and intermittent distances, every $20 \mathrm{~m}$, between the transects (Figure 3). This (C) Antiquity Publications Ltd, 2018 


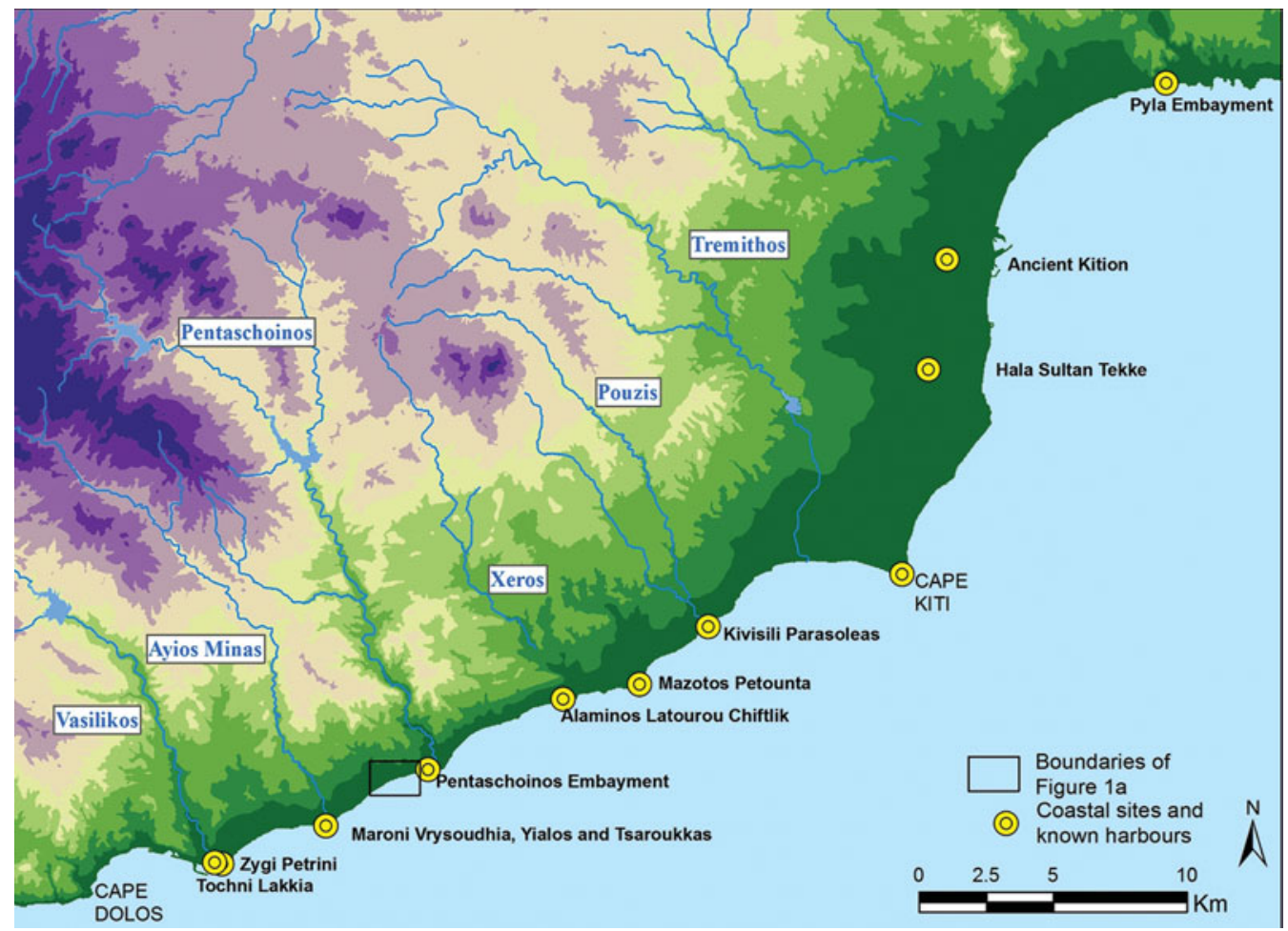

Figure 2. Late Bronze Age to Late Roman coastal sites along the south-central coast of the island (produced on ArcGIS by the author using a basemap with permission from the DLS).

comparison concludes with a table that quantifies the net shoreline movement along each transect (Figure 4).

The results of this classification process highlight the locations that have experienced higher rates of erosion (indicated with red and orange) since the 1960s, and which, accordingly, require more frequent archaeological recording. This classification is stored in a relational database along with photographs, illustrations, historical and cartographical references, aerial photographs and quantifiable photogrammetric models (Figure 5). The combination of these data forms the core information for coastal archaeological risk assessment, which in turn can inform strategies for coastal monitoring by directing endeavours to the most vulnerable areas.

\section{Conclusion}

The results of this project enable the assessment of erosion risk on known sites and thus help to prioritise the monitoring of the most endangered areas. They can also provide information for the recovery of otherwise unknown sites. While the use of the Digital Shoreline Analysis System highlights areas that are more vulnerable to coastal erosion, it also demonstrates the large number of locales that have potentially lost visible evidence of past maritime interactions. Future research will focus on the 


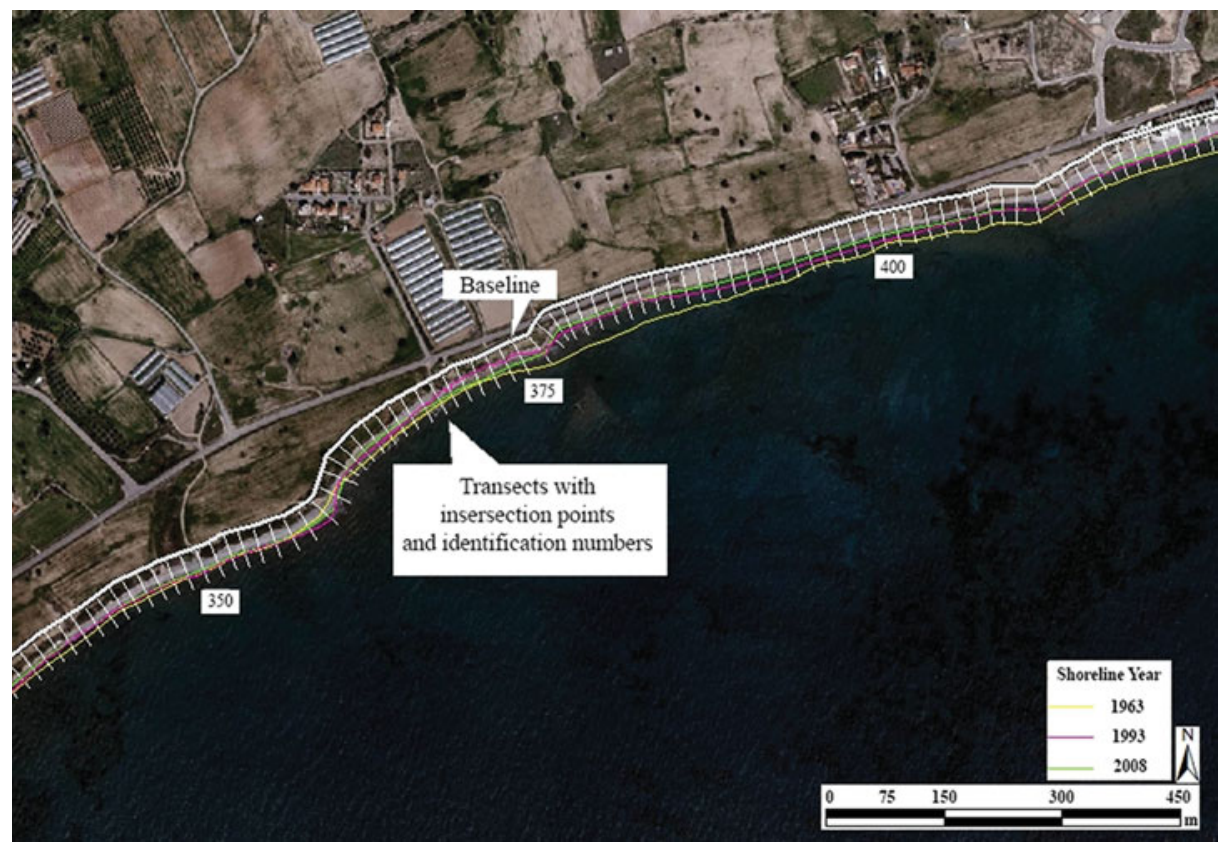

Figure 3. The components of the Digital Shoreline Analysis System function in ArcGIS (produced on ArcGIS by the author with an aerial photograph used with permission from the DLS). The shorelines of 1963 (yellow), 1993 (pink) and 2008 (green) are superimposed on a 2014 aerial photograph (provided by and used with permission from the DLS). A white baseline parallel to the shoreline and a series of white transects perpendicular to the shoreline were produced on the Digital Shoreline Analysis System (ArcGIS) and subsequently used to measure the historical changes in the location of the coastline.

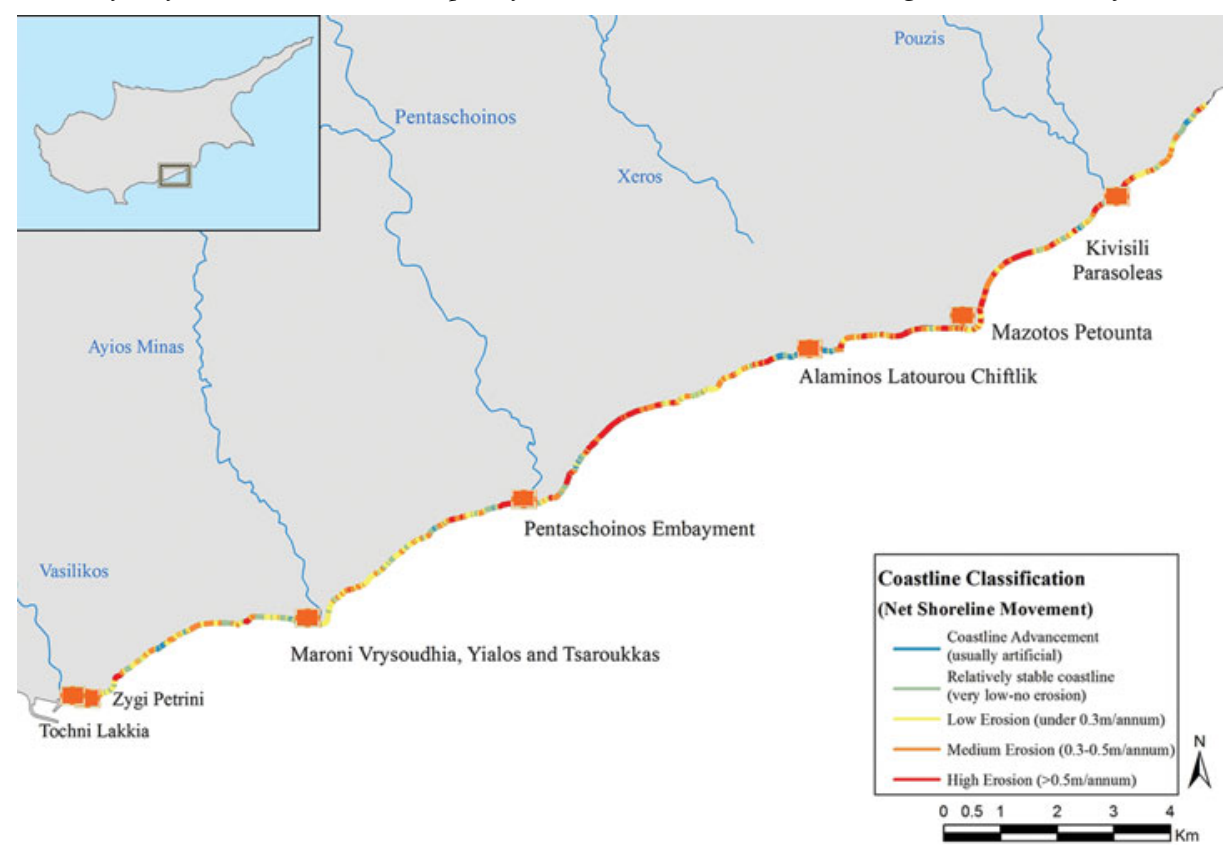

Figure 4. Classification of coastal erosion (high, medium, low) according to the results of the Digital Shoreline Analysis System analysis used to inform future research on maritime archaeology (produced on ArcGIS by the author).

(C) Antiquity Publications Ltd, 2018 


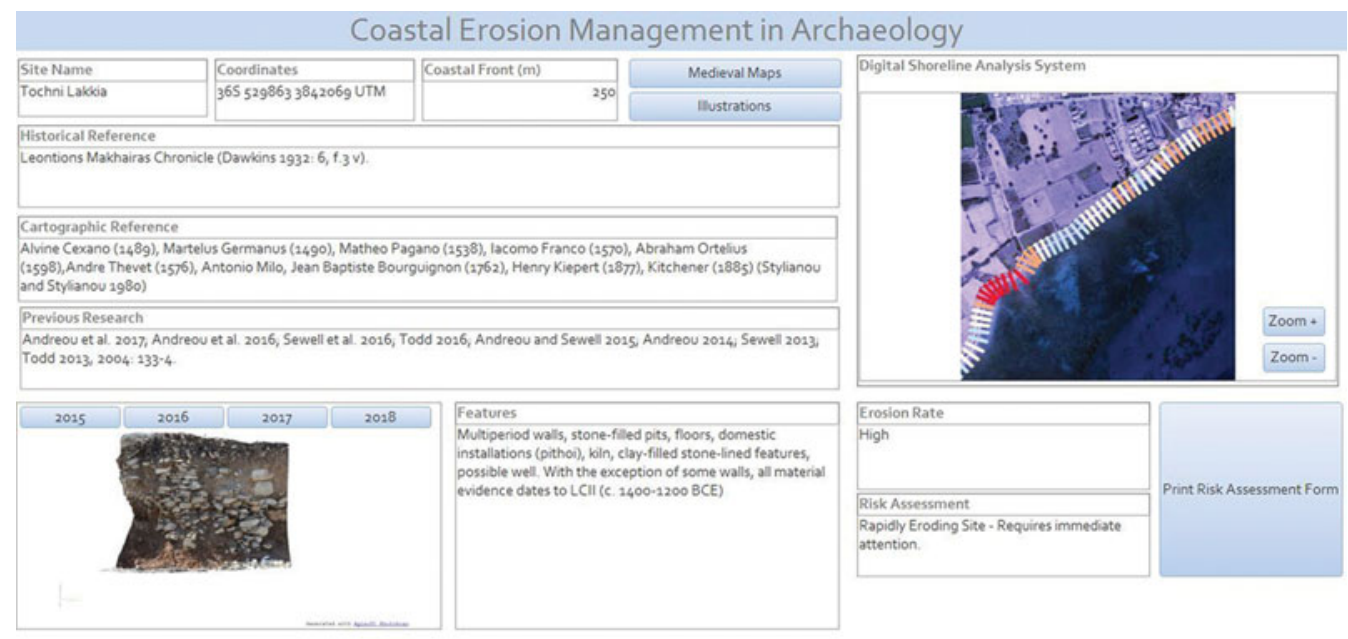

Figure 5. Example entry (the site of Tochni-Lakkia) in the relational database showing information used to develop risk assessments for different coastal sites.

development of GeoApps_mobile apps that collect, store and analyse georeferenced data-to accommodate crowd-sourced information on the location of eroding features.

\section{Acknowledgements}

I wish to thank the Department of Antiquities, Cyprus, for permission to carry out this work, and the Department of Lands and Surveys for permission to use geographical information. This research was funded by the Honor Frost Foundation and the Council of British Research in the Levant.

\section{References}

Agapiou, A., V. Lysandrou \& D. Hadjimitsis. 2017. The Cyprus coastal heritage landscapes within maritime spatial planning process. Journal of Cultural Heritage 23: 28-36. https://doi.org/10.1016/j.culher.2016.02.016

Andreou, G.M. \& D.A. Sewell. 2015. Tochni-Lakkia revealed: reconsidering settlement patterns in the Vasilikos and Maroni Valleys, Cyprus, in H. Matthäus, B. Morstadt \& C. Vonhoff (ed.) PoCA (Postgraduate Cypriot Archaeology) 2012: 198-219. Newcastle: Cambridge Scholars.

Andreou, G.M., R. Opitz, S.W. Manning, K.D. Fisher, D.A. Sewell, A. Georgiou \& T. URBAN. 2017. Integrated methods for understanding and monitoring the loss of coastal archaeological sites: the case of Tochni-Lakkia, Cyprus. Journal of Archaeological Science Reports 12: 197-208. https://doi.org/10.1016/j.jasrep.2017.01.025
Demesticha, S. 2015. Gone with the waves: scattered Roman amphorae in shallow waters around Cape Kiti, Cyprus, in S. Demesticha (ed.) Per terram, per mare: seaborne trade and the distribution of Roman amphorae in the Eastern and Central Mediterranean: 55-76. Uppsala: Åström.

Georgiou, G. 2013. An Early Christian baptistery in the south coast of Cyprus. Cahier du Centre d'Études Chypriotes 43: 117-26. https://doi.org/10.3406/cchyp.2013.1058

Knapp, A.B. \& S. Demesticha. 2017. Mediterranean connections: maritime transport containers and seaborne trade in the Bronze and Early Iron Ages. London: Routledge.

Manning, S.W., D. Collon, D.H. Conwell, H.-G. Jansen, L. Steel \& A. Swinton. 1994. 'Tsaroukkas, Mycenaeans and Trade' project: preliminary report on the 1993 season. Report of the Department of Antiquities, Cyprus: 83-106. 
Manning, S.W., S.J. Monks, D.A. Sewell \& S. Demesticha. 2000. Late Roman type 1A amphora production at the Late Roman site of Zygi-Petrini, Cyprus. Report of the Department of Antiquities, Cyprus: 233-57.

O’RourKE, M.J.E. 2017. Archaeological site vulnerability modelling: the influence of high impact storm events on models of shoreline erosion in the western Canadian Arctic. Open Archaeology 3: 1-17. https://doi.org/10.1515/opar-2017-0001
Radosavljevic, B., H. Lantuit, W. Pollard, P. Overduin, N. Coutur, T. Sachs, V. Helm \& M. FriTz. 2016. Erosion and flooding - threats to coastal infrastructure in the Arctic: a case study from Herschel Island, Yukon Territory, Canada. Estuaries and Coasts 39: 900-15. https://doi.org/10.1007/s12237-015-0046-0

Thieler, E.R., E.A. Himmelstoss, J.L. Zichichi \& E. Ayнan. 2009. Digital Shoreline Analysis System (DSAS) version 4.0 - an ArcGIS extension for calculating shoreline change: US Geological Survey Open-File Report 2008-1278. Reston (VA): US Geological Survey. 